\title{
Studies on the diagnostic value of an immuno- fluorescence test for EB virus-specific IgM
}

\author{
JOAN M. B. EDWARDS AND D. A. MCSWIGGAN \\ From the Virus Reference Laboratory, The Central Public Health Laboratory, Colindale, London, and \\ the Department of Microbiology, Central Middlesex Hospital, London
}

SYNOPSIS A modification of the test for EB virus/IgM introduced by Schmitz and Scherer (1972) is described. It is simple and gives reproducible results.

EB virus/IgM was demonstrated in all but one case of infectious mononucleosis and in students with minor illness shown to have acquired EB virus/IgG recently. Unlike the EB virus/IgG, the IgM disappears within a few months. Although the Paul-Bunnell-Davidsohn test is still the test of choice for the diagnosis of infectious mononucleosis, the EB virus/IgM test could be useful to establish a diagnosis of current or recent EB virus infection where the Paul-Bunnell-Davidsohn test was negative or equivocal.

An absorbed specific anti IgG fluorescein isothiocyanate (FITC) conjugate is used in the indirect immunofluorescence test for detecting the presence of EB virus antibody in human sera (Niederman, McCollum, Henle, and Henle, 1968). This is because the EB3 cell line usually used as the source of EB viral capsid antigen has IgM on the surface of the cells with which a general anti-immunoglobulin conjugate would react giving non-specific staining. Unfortunately during an attack of infectious mononucleosis the EB-virus-specific IgG has usually reached a maximum titre by the time the first diagnostic blood sample is taken. As the titre thereafter remains steady for years the EB virus IgG level is of little use in diagnosis without a recent preillness serum to test in parallel (Joncas, 1972). This is rarely available. Niederman, Evans, Subrahmanyan, and McCollum (1970) at Yale University and in Britain the University Health Physicians and Public Health Laboratory Service Laboratories (1971) in their studies of infectious mononucleosis in students had access to such sera. They found close agreement in this age group between the EB virus IgG conversion from negative to positive and a positive heterophil antibody test or Paul-BunnellDavidsohn (PBD) test. The PBD test is therefore the test of choice in the diagnosis of infectious mononucleosis in this and older age groups. There is some evidence, however, that the PBD may not be found positive in some patients with infectious

Received for publication 1 May 1974. mononucleosis who are under the age of 14 (Starling and Fernbach, 1968).

Schmitz, Volz, Krainick-Riechert and Scherer (1972) provide evidence of success with an EB-virusspecific IgM test in the under-14 age group. They used the HR-1K cell line which is devoid of cell surface immunoglobulin. In addition they showed that the macroglobulin (IgM) antibody was given more opportunity of reacting in competition with the smaller IgG molecule if the test serum was incubated for three hours (Schmitz and Scherer, 1972). Banatvala, Best, and Waller (1972) have also described an EB virus IgM test but did not recommend it for routine use because of the need for fractionation and absorption of the sera. Each group found evidence in eight patients that EB virus IgM appeared in the serum at the time of the illness but disappeared within a few months.

In a British university study the Virus Reference Laboratory of the Public Health Laboratory Service acquired serial specimens of sera from students with varied clinical histories and EB virus IgG patterns. Besides these a collection was made of sera from patients with Hodgkin's disease and routine sera submitted for the Paul-Bunnell-Davidsohn test. It seemed possible that an examination of these sera by an adaptation of the EB virus IgM technique of Schmitz and Scherer might provide a means of answering the following questions:

1 Can the adapted technique be performed as easily as the Henle EB virus IgG test and give reproducible results? 
2 Can the disappearance of EB virus IgM between one and six months after the onset of infectious mononucleosis be confirmed in a larger number of cases?

3 Can EB virus IgM be detected in students who convert from EB virus IgG negative to positive with minimal or no symptoms and does this IgM disappear at the same rate as in clinical infectious mononucleosis?

4 Students who have an EB virus IgG-positive titre on entry to the university can be assumed to have been infected with EB virus before arrival. Can an EB virus IgM ever be detected at a later date either (a) without overt illness or (b) during an attack of influenza, an example of an acute virus infection, or (c) a 'glandular fever' type illness. In other words, is the presence of EB virus IgM always an indication of recent primary infection with EB virus?

5 Can EB virus IgM be detected in patients with Hodgkin's disease?

\section{Materials and Methods}

The source of serum samples was as follows:(1) 66 sera sent to Neasden Public Health Laboratory for routine Paul-Bunnell-Davidsohn tests; (2) sera from 36 cases of infectious mononucleosis in students taken both during illness and up to three years after infection; (3) sera from 30 students who developed EBV IgG between their serum specimen in October 1970 at entry to the university and the following May 1971 and from whom a specimen was again obtained two years later in May 1973; (4) 139 students all of whose sera contained EB virus IgG on entry to the university, including (a) 69 students who gave another serum specimen three years later in connexion with a rubella vaccination programme, (b) 42 students bled during an attack of influenza in January 1973, and (c) 28 students who developed a clinical 'glandular fever' type illness during their university careers; (5) 32 patients with Hodgkin's disease provided by Dr Peckham of the Royal Marsden Hospital.

IMMUNOFLUORESCENCE CELLS AND REAGENTS The EB3 cell line obtained from Professor M. A. Epstein in 1968 was used for the IgG tests. The HR-1K cell line was obtained from Dr Joncas of Montreal in 1973. Both cell lines were maintained for the preparation of coverslips as described by Pereira, Blake, and Macrae (1969).

A standard positive EB IgM control serum was sent by Dr Schmitz of Freiburg.

A research sample of specific sheep antihuman IgG/FITC conjugate was given to the Public Health Laboratory Service for the university survey by the
Wellcome Research Laboratories. The FITC-conjugated sheep specific antihuman IgM was obtained from the Wellcome Research Laboratories for this investigation. The specificity in indirect immunofluorescence of these conjugates has been tested on preparations of Brucella abortus suspension treated with both whole sera and also the density gradient fractions of human sera which are known to contain either (a) only IgG, (b) only IgG and IgA, or (c) IgG, IgA, and IgM Brucella antibodies when examined by the method previously described for standardization of antihuman FITC conjugates (Edwards, 1969) using monospecific conjugates.

The technique used for the Paul-Bunnell-Davidsohn or heterophil antibody test was that described by Davidsohn and Henry (1969). A serum was considered positive when the agglutinating titre after absorption with guinea-pig kidney suspension was more than four times the titre after absorption with ox cell suspension.

The EB virus IgG was detected by the indirect immunofiuorescence technique of Henle and Henle (1966). For the university survey the antibody titres were recorded but for the purpose of this paper sera are classified as positive or negative according to their reaction at a dilution of 1 in 8 .

The EB virus IgM was detected by the technique of Schmitz and Scherer (1971) modified to give the following schedule:

HR-1K cells lightly centrifuged and resuspended in phosphate-buffered saline were distributed on coverslips, dried in air, and fixed in acetone for 10 minutes at room temperature.

Serum specimens were diluted 1 in 8 in phosphatebuffered saline and allowed to react on the cell preparations in a damp atmosphere for three hours at $37^{\circ} \mathrm{C}$.

The slips were then washed for 10 minutes in phosphate-buffered saline and after drying in air were treated with FITC conjugated sheep antihuman IgM and incubated in a damp atmosphere for one hour at $37^{\circ} \mathrm{C}$.

After washing with agitation for $\mathbf{3 0}$ minutes with three changes of buffer, the slips were mounted with a polyvinyl alcohol-glycerol mountant (Heimer and Taylor, 1974) and examined on a Union inverted microscope as described by Heimer and Taylor (1972). The microscope incorporates a tungsten halogen light source (150 watt and 24 volt) and a primary all dielectric interference filter (Rygaard and Olsen 1969,1971$)$ specifically designed for use with microscopical preparations treated with FITClabelled antibodies together with a matching secondary glass filter. The condenser used was the Tiyoda dark field type with a toric lens. 


\section{Results}

The correlation between Paul-Bunnell-Davidsohn tests and the presence of EB virus IgM in 66 routine diagnoses are shown in table I. Only one disagreement was found between these results. The PaulBunnell-Davidsohn and EB virus IgM tests were performed in different laboratories without knowledge of the others' results. The tests for the virus IgM were repeated and gave the same results.

The 36 cases of infectious mononucleosis all had positive Paul-Bunnell-Davidsohn tests and EB virus IgM tests in specimens taken at onset or within one month of onset (table II). A specimen was available in all but six between six months and three years after the illness. They were all EB virus IgG positive and IgM negative. In six who had specimens taken between three and six months two were already negative for EB virus IgM but four still contained a trace.

\begin{tabular}{|c|c|c|c|c|}
\hline $\begin{array}{l}\text { Paul-Bunnell- } \\
\text { Davidsohn } \\
\text { Positive }\end{array}$ & $\begin{array}{l}\text { EB Virus IgM } \\
\text { and Positive }\end{array}$ & $\begin{array}{l}\text { Paul-Bunnell- } \\
\text { Davidsohn } \\
\text { Positive }\end{array}$ & and & $\begin{array}{l}\text { EB Virus IgM } \\
\text { Negative }\end{array}$ \\
\hline \multicolumn{2}{|r|}{21} & \multicolumn{3}{|c|}{1} \\
\hline $\begin{array}{l}\text { Paul-Bunnell- } \\
\text { Davidsohn } \\
\text { Negative }\end{array}$ & $\begin{array}{l}\text { EB Virus IgM } \\
\text { and Positive }\end{array}$ & $\begin{array}{l}\text { Paul-Bunnell- } \\
\text { Davidsohn } \\
\text { Negative }\end{array}$ & and & $\begin{array}{l}\text { EB Virus IgM } \\
\text { Negative }\end{array}$ \\
\hline \multicolumn{2}{|r|}{0} & \multicolumn{3}{|c|}{44} \\
\hline
\end{tabular}

Table I Sixty-six sera submitted for Paul-BunnellDavidsohn tests
These results suggest that the EB virus IgM is demonstrable soon after the onset of infectious mononucleosis and fades away at some time between four weeks and several months.

Table III shows that the EB virus IgM results in 30 students who were EB virus IgG negative on entry in October had converted to EB virus IgG positive by the following May and who had a further specimen taken two years later. Nine of these had a positive Paul-Bunnell-Davidsohn test in the May specimen and when questioned closely were found to have had a recent illness with sore throat and swollen lymph glands which they did not consider warranted a visit to their own doctor or the student health physician. Six of these nine had EB virus IgM. Of the other 21, 12 had negative Paul-BunnellDavidsohn tests and nine were not tested. All the sera taken two years later were EB virus IgG positive and IgM negative.

Table IV shows that of the specimens taken from 139 students with positive EB virus IgG tests on entry all were negative for EB virus IgM except one entry specimen. This specimen was then tested by the Paul-Bunnell-Davidsohn test and found positive. Information was not available on whether this student had had a recent illness.

Sera from 32 cases of Hodgkin's disease were tested for EB virus IgG and IgM antibody. All but two were positive in the EB virus IgG test. One was weakly positive in the EB virus IgM test but this serum gave a negative Paul-Bunnell-Davidsohn result. Dr Schmitz was unable to confirm this weak positive result.

\begin{tabular}{lllll}
\hline Test & Serum before Illness & $\begin{array}{l}\text { Serum Taken at Onset } \\
\text { or up to 4 Weeks } \\
\text { after Onset }\end{array}$ & $\begin{array}{l}\text { Serum Taken between } \\
3 \text { and } 6 \text { Months (6 cases) }\end{array}$ & $\begin{array}{l}\text { Serum Taken from } 6 \text { Months } \\
\text { to } 3 \text { Years after Illness } \\
\text { (30 cases) }\end{array}$ \\
\hline EB virus IgM & 36 negative & 36 positive & $\begin{array}{l}2 \text { negative } \\
4 \text { trace readings only } \\
6 \text { positive }\end{array}$ & 30 negative \\
EB virus IgG & 36 negative & 36 positive & 30 positive \\
\hline
\end{tabular}

Table II Specific EB virus IgM and IgG results in 36 cases of infectious mononucleosis all with positive PaulBunnell-Davidsohn tests

\begin{tabular}{llcl}
\hline Test & October 1970 & May 1971 & May 1973 \\
\hline EB virus IgM & 30 negative & 6 positive & 30 negative \\
EB virus IgG & 30 negative & 24 negative & 30 positive \\
Paul-Bunnell-Davidsohn & Not tested & 30 positive & Not tested \\
& & 9 positive & 9 nogative \\
& & 9 not tested & \\
\hline
\end{tabular}

Table III Results of EB virus IgM and IgG and Paul-Bunnell-Davidsohn tests in thirty students with EB virus antibody without reported illness

All Paul-Bunnell-Davidsohn positive

$3^{*}$ 


\begin{tabular}{|c|c|c|c|c|}
\hline \multirow[t]{2}{*}{ Category of Students } & \multirow[t]{2}{*}{ Number of Students } & \multicolumn{3}{|c|}{ Serum Specimens taken at } \\
\hline & & Entry & Illness & Three Years after Entry \\
\hline Normal (rubella vaccine trial) & 69 & $\begin{array}{l}68 \text { negative } \\
1 \text { positive }\end{array}$ & None & 69 negative \\
\hline $\begin{array}{l}\text { Influenza cases } \\
\text { 'Glandular fever' }\end{array}$ & $\begin{array}{l}42 \\
28\end{array}$ & $\begin{array}{l}42 \text { negative } \\
28 \text { negative }\end{array}$ & $\begin{array}{l}42 \text { negative } \\
28 \text { negative }\end{array}$ & $\begin{array}{l}\text { None } \\
\text { None }\end{array}$ \\
\hline
\end{tabular}

Table IV Results of EB virus IgM tests in 139 students all EB virus positive on entry and thereafter

\section{Discussion}

Close correlation has been shown between the positive Paul-Bunnell-Davidsohn test and the presence of EB virus IgM. However, it is known that these two antibodies are different in their antigen specificity as absorption of the serum with ox tissues has no effect on the EB virus IgM level (Hampar, Hsu, Martos, and Walker, 1971). It has been suggested that patients with infectious mononucleosis under 10 years of age may not develop the antibody responsible for the positive Paul-Bunnell-Davidsohn test. In these instances EB virus IgM may be a useful test. In the routine infectious mononucleosis diagnostic samples tested the Paul-Bunnell-Davidsohn and EB virus IgM were in agreement with one exception but few patients were under 10 years of age. Estimation of EB virus IgM may sometimes be useful in cases of doubtful diagnosis when the serum for the Paul-Bunnell-Davidsohn test was not taken early enough in the disease. Occasionally that test may still be positive as positive reactions in the two tests do not disappear simultaneously in all cases. However in the six cases of infectious mononucleosis (table II) where serum was taken between three and six months after the onset of the illness, although six still had a positive Paul-Bunnell-Davidsohn test, only four showed trace readings in the EB virus IgM test and two were negative. In the series of 30 students (table III) developing antibody without illness between October and May only six had positive EB virus IgM whereas nine had a positive Paul-Bunnell-Davidsohn test. As these May specimens were taken some time after the illness the presence of a positive test in these students without EB virus IgM also suggests, although the numbers are small, that the EB virus IgM falls below a level demonstrable by this technique before the Paul-Bunnell-Davidsohn positive reaction disappears.

In this study only one of 32 cases of Hodgkin's disease showed EB virus IgM. Conditions of storage of this set of specimens may not have been optimal and IgM is the immunoglobulin most likely to degrade with changes in temperature. Banatvala, et al (1972) found no positive EB virus IgM in three cases. Schmitz and Scherer (1971) claim positive results in three early cases and suggest that their success might be due to the stage of the disease when the cases were tested or to the greater sensitivity of their test. As they use a two-stage fluorescent antiglobulin test they will have a more sensitive test than that reported in this paper as each extra stage multiplies the antigen-combining sites. An extra stage can also increase non-specific staining but there is no evidence that Schmitz and Scherer encountered this problem.

Of specimens of sera taken one to three years after the individual was known to have EB virus IgG antibody, none showed the presence of EB virus IgM. These specimens were taken from students both normal and during illnesses resembling infectious mononucleosis and from confirmed cases of influenza during an epidemic. It seems that a reappearance of the EB virus IgM after the primary infection with EB virus is not likely to occur.

We are grateful to Dr Marguerite Pereira for her advice and encouragement; to Dr Joncas for his interest and for supplying the HR-1K cells; $\mathrm{Dr}$ Schmitz for helpful discussion and his confirmation of some of these positive and negative sera in his test; to Mrs Eileen Sargent of the Central Middlesex Public Health Laboratory for providing serum samples and the results of Paul-Bunnell-Davidsohn tests; to Dr Irene Batty of the Wellcome Research Laboratories for giving the monospecific antihuman IgG/FITC conjugate for the university survey; to Dr T. M. Pollock, Mr W. B. Fletcher, and Mrs Gwendoline Smith of the Epidemiology Research Laboratory, and Dr J. Scott and Dr S. E. Finlay of Keele and Nottingham University Student Health Services for access to the clinical records of the student cases; and to Mrs Marian Joy for her secretarial assistance.

\section{References}

Banatvala, J. E., Best, J. M., and Waller, D. K. (1972). Epstein-Bar virus specific IgM in infectious mononucleosis, Burkitt lymphoma and nasopharyngeal carcinoma. Lancet, 1, 1205-1208.

Davidsohn, I., and Henry, J. B. (1969). Todd-Sanford Clinical Diagnosis by Laboratory Methods 14th ed. Saunders, Philadelphia.

Edwards, J. M. B. (1969). A test with Brucella antigen and antisera for assessing the titre of fluorescein conjugates of anti-human globulin. J. med. Microbiol., 2, 555-561. 
Hampar, B., Hsu, K. C., Martos, M., and Walker, J. L. (1971). Serological evidence that a herpes-type virus is the etiological agent of heterophile-positive infectious mononucleosis. Proc. nat. Acad. Sci. (Wash.), 68, 1407-1411.

Heimer, G. V., and Taylor, C. E. D. (1972). Improved immunofluorescence obtained with a tungsten halogen lamp in a modified inverted microscope. J. clin. Path., 25, 88-93.

Heimer, G. V., and Taylor, C. E. D. (1974). Improved mountant for immunofluorescence preparations. J. clin. Path., 27, 254-256.

Henle, G., and Henle, W. (1966). Immunofluorescence in cells derived from Burkitt's lymphoma. J. Bact., 91, 1248-1256.

Joncas, J. H. (1972). Clinical significance of the EB herpes virus infection in man. Progr. med. Virol., 14, 200.

Niederman, J. C., McCollum, R. W., Henle, G., and Henle, W. (1968). Infectious mononucleosis. Clinical manifestations in relation to EB virus antibodies. J. Amer. med. Ass., 203, 205-209.

Niederman, J. C., Evans, A. S., Subrahmanyan, L., and McCollum, R. W. (1970). Prevalence, incidence and persistence of EB virus antibody in young adults. New Engl. J. Med., 282, 361-365.
Pereira, M. S., Blake, J. M., and Macrae, A. D. (1969). EB minus antibody at different ages. Brit. med. J., 4, 526-527.

Rygaard, J., and Olsen, W. (1969). Interference filters for improved immunofluorescence microscopy. Act. path. microbiol. scand., 76, 146-148.

Rygaard, J., and Olsen, W. (1971). Determination of characteristics of interference filters. Ann. N.Y. Acad. Sci., 177, 430-433.

Schmitz, H., and Scherer, M. (1972). IgM antibodies to Epstein-Barr virus in infectious mononucleosis. Arch. ges. Virusforsch., 37, 332-339.

Schmitz, H., Volz, D., Krainick-Riechert, C., and Scherer, M. (1972). Acute Epstein-Barr virus infections in children. Med. Microbiol. Immunol., 158, 58-63.

Starling, K. A., and Fernbach, D. J. (1968). Infectious mononucleosis in the pre-school child. J. Amer. med. Ass., 203, 810.

University Health Physicians and P.H.L.S. Laboratories (1971). Infectious mononucleosis and its relationship to EB virus antibody. Brit. med. J., 4, 643-646.

\section{Reports and Bulletins prepared by the Association of Clinical Biochemists}

The following reports and bulletins are published by the Association of Clinical Biochemists. They may be obtained from The Publishing Department, British Medical Journal (ACB Technical Bulletins), B.M.A. House, Tavistock Square, London WC1H 9JR. Overseas readers should remit by British Postal or Money Order.

\section{SCIENTIFIC REPORTS (price $£ 1 \cdot 00 / \$ 2.00$ each)}

3 Automatic Dispensing Pipettes: an assessment of 35 commercial instruments September 1967 P. M. G. BROUGHTON, A. H. GOWENLOCK, G. M. WIDDOWSON, and K. A. AHLQUIST

4 An Evaluation of five Commercial Flame Photometers suitable for the Simultaneous Determination of Sodium and Potassium March 1970 P. M. G. BROUGHTON and J. B. DAWSON

\section{SCIENTIFIC REVIEWS (price $£ 1 \cdot 00 / \$ 2.00$ each)}

1 The Assessment of Thyroid Function March 1971 F. V. FLYNN and J. R. HOBBS

2 Renal Function Tests Suitable for Clinical Practice January 1972 F. L. MITCHELL, N. VEALL, and R. W. E. WATTS

TECHNICAL BULLETINS (price $£ 1.00 / \$ 2.00$ each)

9 Determination of Urea by AutoAnalyzer November 1966 RUTH M. HASLAM

11 Determination of Serum Albumin by AutoAnalyzer using Bromocresol Green October 1967 B E. NORTHAM and G. M. WIDDOWSON

13 An Assessment of the Technicon Type II Sampler Unit March 1968 B. C. GRAY and G. K. MCGOWAN

14 Atomic Absorption Spectroscopy: an outline of its principles and a guide to the selection of instruments May 1968 J. B. DAWSON and P. M. G. BROUGHTON

15 A Guide to Automatic Pipettes (2nd edition) June 1968 P. M. G. BROUGHTON

16 A Guide to Automation in Clinical Chemistry May 1969 P. M. G. BROUGHTON

17 Flame Photometers: a comparative list of 17 instruments readily available in Britain August $1969 \mathrm{P}$. WILDING
19 Spectrophotometers: a comparative list of low-priced instruments readily available in Britain May 1970 C. E. WILDE and P. SEWELL

20 Quantities and Units in Clinical Biochemistry June 1970 P. M. G. BROUGHTON

21 Filter Fluorimeters: A comparative list of 18 instruments September 1970 H. BRAUNSBERG and $s$. S. BROWN

22 Bilirubin Standards and the Determination of Bilirubin by Manual and Technicon AutoAnalyzer Methods January 1971 BARBARA BILLING, RUTH HASLAM, and N. WALD

23 Interchangeable Cells for Spectrophotometers and Fluorimeters September 1971 S. S. BROWN and A. H. GOWENLOCK

24 Simple Tests to Detect Poisons March 1972 B. w. MEADE et al.

25 Blood Gas Analysers May 1972 K. DIXON

26 Kits for Enzyme Activity Determination September 1972 S. B. ROSALKI and D. TARLOW

27 Assessment of Pumps Suitable for Incorporation into Existing Continuous Flow Analytical Systems November 1972 A. FLECK et al.

28 Routine Clinical Measurements of Transferrin in Human Serum September 1973 K. DIXON

29 Control Materials for Clinical Biochemistry (5th editicn) September 1973 J. F. STEvens

30 Notes on the Quality of Performance of Serum Cholesterol Assays September 1973 s. S. BRowN 